\title{
A Preliminary Investigation of the Pragmatic Abilities of a Group of Language Disordered Children
}

\author{
Lindy Rosen, BSc (Logopaedics) (Cape Town) \\ Rosemary Keen, M Sc (London) \\ Department of Logopaedics \\ University of Cape Town, Cape Town
}

\section{ABSTRACT}

The communicative acts, conversational acts, and breakdown repair abilities of six language-disordered children with a syntactic age of \pm 3 years old as determined by the LARSP (Cnystal, Fletcher, Garman: 1976) were investigated. Sampling of each subject involved two separate naturalistic interactions with a familiar adult and a language disordered peer. The data obtained from the transcriptions were analysed in terms of linguistic and nonlinguistic behaviours on the Communication Profile by Wollner and Geller (1982). Specific patterns of deficit and strengths were observed and these trends were related to recent literature in this area. The study emphasises that there is as much heterogeneity in the pragmatic skills as in the other communication skills of language disordered children, although this is due to some extent to the limitations of assessment in naturalistic settings. It also indicates individual areas of pragmatic deficit that require remediation.

\section{OPSOMMING}

Die kommunikasiehandeling, gesprekshandeling en herstelmoontlikhede van uitvalle by ses kinders met taalsteurnis, met 'n sintaktiese ouderdom van \pm 3 jaar volgens die LARSP (Crystal, Fletcher, Garman: 1976), is ondersoek. Taalmonsters van elke toetspersoon is verkry deur twee aparte naturalistiese interaksies met 'n bekende volwasse en 'n taalversteurde klasmaat. Die data wat verkry is van die transkripsies is geanaliseer in terme van linguistiese en nie-linguistiese gedrag deur die gebruik van "The Communication Profile" van Wollner en Geller (1982). Bepaalde patrone van uitvalle en sterkpunte is opgemerk en hierdie neigings is vergelyk met onlangse literatuur oor hierdie aspek. Die studie beklemtoon dat daar net soveel heterogeniteit in die pragmatiese vermoëns van taalversteurde kinders voorkom, as in ander kommunikasie-vermoëns, alhoewel dit in 'n sekere mate te wyte is a an beperkings van ondersoekmoontlikhede in 'n naturalistiese opset. Die studie dui ook op individuele aspekte van pragmatiese uitvalle wat remediëring vereis.

\section{INTRODUCTION}

Bates (1976) introduced pragmatics into the field of speech therapy and defined it as 'the rules governing the use of language in context.' Subsequent authors, e.g. Savich (1983), Prinz (1982), Prutting \& Kirchner (1983), confirm this description. The study of pragmatics then considers communicative intentions, presuppositions, social context variables and social organisation of discourse.

Communication is thus much more than issuing and receiving a message. It deals with issuing a message in the most appropriate form for conveying intended meanings to a particular person for particular effects. Muma (1975) verifies that both speaker and listener are active participants in the conversational game. Donahue (1983) discusses this familiar metaphor used to illustrate a model of conversational turntaking as a network for reciprocal obligations. She compares the conversational game to that of tennis and notes how conversation is governed by Grice's (1975) co-operative principle, whereby both partners agree to work at keeping the conversational ball in play. She explains that just as the most skilled tennis player occasionally misses the ball or does not manage to get it over the net, so too, conversational partners can have communication breakdowns. Both partners are then obliged to work at reintegrating the dialogue. Co-operative listeners are expected to signal to the speakers when a remark is not understood and speakers are then obliged to revise or repeat the initial utterance. When one player is more skilful than another, the superior player is expected to compensate by assuming greater responsibility for keeping the game going (Donahue, 1983). Thiscan be seen in children as young as three or four yearsold who modify their speech when speaking to babies as opposed to adults (Shatz \& Gelman (1973) and Sachs \& Devin as cited by Fey, Leonard \& Wilcox (1981)).

Hymes, as cited by Roth \& Spekman (1984a), states that in addition to learning the phonologic, semantic and syntactic rules of language, the child must master the rules that underlie how language is used for the purpose of communication. A developmental sequence of pragmatic acquisition has been described by several authors. Wiig \& Semel (1986) cite various perspectives from which this development can be viewed, while Ochs \& Schieffelin (1979) document the following trends: the child's move away from reliance on the immediate context towards greater reliance on nonsituated knowledge; the child's expanding knowledge of conversation for carrying out particular social acts.

Creaghead (1982) comments that the current interest in pragmatic development has led to the identification of communication deficits in children which had previously been overlooked or considered outside the realm of speech therapy. Numerous studies have recently been carried out on pragmatics in language-disordered children. Research has revealed significant conflicting data. Gallagher \& Darnton (1978) and Brinton and Fujiki (1982) report that the language disordered child uses his language in a qualitatively different way from the normal. In contrast Van Kleeck \& Frankel (1981) found that the language disordered children they studied used the linguistic devices they investigated in a manner essentially the same as normal children with a similar developmental trend emerging in their subjects. 
Prutting \& Kirchner (1983) state that simply because the child does not possess linguistic and structural sophistication does not necessarily imply that he does not acknowledge the partnership and meet the obligation of conversation. Even if the child does not give the exact linguistic response, he may, for example, be aware that an answer is required. They conclude that, given the restricted range of linguistic options available to the disordered communicator, he may be forced to rely on pragmatic strengths (e.g. repetition of the previous utterance) to engage in co-operative conversation to sustain interaction. Prutting \& Kirchner (1983) describe a group of children who display pragmatic assets which allow them to attain a higher level of communicative competence in the context of otherwise limited linguistic ability.

Donahue (1983) also cites various studies portraying the young language disordered and older learning-disabled child as eager to fulfil his conversational responsibility while compensating for linguistic inadequacies. It was Donahue (1983) who likened these children to tennis players who have a limited set of strokes and seem to hover on the edge of the interaction, watching for an easy opening into the game. She stresses that by seeking out opportunities for participating that provide nonlinguistic and contextual support, the child gives the appearance of keeping the conversational ball in play but simultaneously he is quite adept at avoiding situations that demand linguistic complexity and conversational initiative. The young language impaired child is thus described by Savich (1983) and Donahue (1983) as adopting an unassertive style which contributes to a cycle of social and linguistic delay in the child as he develops. As Prinz (1982) points out, preliminary evidence indicates that the developmental course in pragmatics precedes greater variation and differentiation in expressive and receptive language skills. It also seems apparent that the non-verbal system of communication assumes a very important integrating role in the social-cognitive development process (Prinz 1982).

Clearly the individual pragmatic behaviours of language disordered children should become part of the language assessment protocol. Roth \& Spekman (1984a) emphasise that whereas the development of formalised pragmatic assessment tools must await a clearer delineation of a normal developmental sequence, it is possible to draw on available empirical and theoretical literature to construct an organisational framework for analysing performance in this area. They stress, however, that assessment in the area of pragmatics is still very much in the experimental stages and that our knowledge of normal developmental sequences is far from complete.

Part of the framework for analysing pragmatic skills is the communicative setting. Gallagher (1983) cites studies by Stark and Tallal of language development in normal and specifically language impaired children that have demonstrated that there are several major contextual paramaters that seem important for language assessment. Familiarity seems to be one of the most important factors, with more social and complex play occurring if young children are familiar with each other (Doyle, Connolly \& Rivest, cited by Gallagher, 1983). Craig (1983) reports that skilled clinicians of language impaired children can increase the frequency with which the child has opportunities for experiencing conversational demands and rules for obtaining representative samples of language use for analysis.

Another part of the framework for analysing pragmatic skills is the assessment tool. The literature describes various profiles that have recently emerged for the purpose of analysing and explaining pragmatic abilities of children and adults with varying communicative disorders. The majority of the sources are designed for use with children (Dore, Gearhart \& Newman (1978), Corsaro (1979), and Wollner \& Geller (1982)) in contrast to Penn's Profile of Communicative Appropriateness (1985) that was specifically designed for adults with a degree of linguistic and structural sophistication required of participants.

While it is important to study normal non-verbal communication in children for further development of assessment material, Prinz (1982) advises that it is also necessary to study language disordered children's use of their limited language skills to determine the characteristics of the cycle of delay to provide guidelines for the determination of global therapy goals on a pragmatic basis. With this in mind, the experimenters chose to obtain samples of conversations from language disordered children for analysis using the available assessment profiles and data on normal and disordered pragmatic development to determine the ways in which pragmatic skills are used by these children, thereby providing information that could possibly be of use in their remediation.

\section{METHOD}

The aim of the study was to determine the range and frequency of conversational acts, communicative acts and response to communication breakdown used by a group of language impaired children in two different communicative settings. These three aspects of pragmatic behaviour were the areas covered by Wollner \& Geller's Communication Profile (1982) which was identified as being the most appropriate of the available assessment material for the subjects of this study.

Subjects

A group of six English-speaking children was selected from fourteen children at the Language Unit attached to the Department of Logopaedics at the University of Cape Town. All these children had been accepted into the Language Unit according to strict admission criteria. Of relevance here is that their intelligence was within the normal range (assessed by a clinical psychologist); hearing was within normal limits (assessed by an audiologist); there was no severe emotional or behaviou; ral disturbance (assessed by a child psychiatrist), and their language was significantly delayed or deviant in production (at least a year's delay on the LARSP) (Crystal, Fletcher \& Gar' man 1976). Their ages ranged from 4.1 years to 4.11 years, with a mean of 4.6 years.

The Ss all had an expressive syntax rated on the LARSP as Stage III merging in to Stage IV, i.e. a language age of approximately 3 years. There were equal numbers of males and females to reduce any language variations that may occur with sex difference. None of the Ss had had therapeutic intervention for pragmatics.

\section{Data Collection}

The Ss were videotape-recorded (National Camcorder video camera) and audio-tape-recorded (Phillips tape recorder) in two separate naturalistic settings of approximately 10 minutes each in the Language Unit (LU):

\footnotetext{
I - semi-structured interaction between the LU's speech therapist and each $\mathrm{S}$
} 
II - unstructured interaction between each S and a LU peer with a similar expressive language age.

The usual LU play and toy material was made available in both settings.

Roth \& Spekman (1984b) note that meaningful, familiar contexts are essential for spontaneous language sampling, as are the provision of motivating activities. These authors state that the ideal assessment process should involve a variety of contexts and that this can be fulfilled by varying communicative partners. The adult partner in Interaction I was able to control to some extent in the semi-structured interaction the potential for a variety of communicative and conversational acts and examples of communication breakdown, whereas the interaction between each pair of language impaired children was entirely spontaneous.

\section{Analysis of the Data}

Each interaction was transcribed according to Ochs's (1979) criteria for transcription. The identified behaviours were then analysed in detail as linguistic and non-linguistic behaviours in both communicative settings on the following profile:

1. Communication Profile (Wollner \& Geller, 1982) (Appendix 1)

This profile evolved from Wollner and Geller's interest in describing the salient features of the communication performance of a group of language impaired children (Wollner \& Geller, 1982).

\subsection{Communicative Acts}

This section of the profile is an adaptation of the work done by Dore, Gearhart \& Newman (1978) in their Profile of Illocutionary Forces which emerged from the study of normal 3 year-olds in a nursery school setting and involved the same naturalistic sampling as the present study.

The communicative acts that the child achieves by using language are grouped in to those that convey content, that regulate conversation and that express attitudes. Each category is divided into subtypes, for example, communicative acts conveying content can be requests, comments, responses or performatives. Definitions for each type are provided in Appendix 2.

The non-linguistic communicative acts identified on the profile are the gestures, intonation patterns, facial expressions and/or vocalizations that either substitute for linguistic behaviour or are required by the listener for comprehension of the verbal message.

\subsection{Conversational Acts}

This section is an adaptation of Corsaro's Profile on Turntaking Abilities (Corsaro(1979)) which was designed for use in adult/child and peer/peer exchanges in children from $21 / 2$ to 5 years. Wollner \& Geller (1982) identified three main functions within this section: topic initiation, topic extension, and topic termination. Definitions of these can be found in Appendix 3 .

\subsection{Communicative Breakdown}

Wollner \& Geller (1982) state that the ability to repair and to signal communication breakdown is often more critical for the language impaired child than it is for normals, as language impaired children are more often participants in communicative failure or disruption.

The two types of behaviour in this section are those concerned with repair offered by the speaker and requested by the listener (Appendix 1).

Wollner \& Geller (1982) note the following advantages of use of this profile:

- Provision is made for conveyance of communicative acts via nonlinguistic devices as well as linguistically.

- Information is included in the profile that can be applied to prelinguistic communicative development as well as to more sophisticated language development. This is very suitable for language disordered children with a young language age.

\section{Statistical Treatment of Data}

The frequency of behaviours on the Communication Profile completed for each subject were computed and subjected to $X 2$ analysis of significance of difference to determine whether any of the subjects was significantly different from his/her peers in any of the pragmatic behaviours, and whether any of the behaviours was used significantly more or less than any of the others by any of the subjects.

\section{RESULTS AND DISCUSSION}

The results of this investigation reveal that the six subjects used a wide range of conversational acts, communication acts, and responses to communication breakdown, although some behaviour categories were not exhibited by every subject. There were, however, many significant differences between the frequencies of use of the various pragmatic behaviours, and also many significant differences between the subjects. Several trends could be identified and these generally conform with those described in the literature.

Table 1: Range of Communicative Acts for all subjects in Interactions I and II

\begin{tabular}{|c|c|c|c|c|c|c|c|}
\hline Subjects & A & $\mathrm{B}$ & $\mathrm{C}$ & $\mathrm{D}$ & $\mathbf{E}$ & $\mathrm{F}$ & Total \\
\hline $\begin{array}{l}\text { Requests } \\
\text { I } \\
\text { II }\end{array}$ & $\begin{array}{l}1 \\
2\end{array}$ & $\begin{array}{l}3 \\
5\end{array}$ & $\begin{array}{l}11^{\star \star *} \\
11^{\star}\end{array}$ & $\begin{array}{l}1 \\
4\end{array}$ & $\begin{array}{l}3 \\
3\end{array}$ & $\begin{array}{c}5 \\
14^{\text {** }}\end{array}$ & $\begin{array}{l}24 \\
39\end{array}$ \\
\hline $\begin{array}{l}\text { Commen } \\
\text { I } \\
\text { II }\end{array}$ & $\begin{array}{r}6 \\
13 \\
\end{array}$ & $\begin{array}{l}15 \\
25\end{array}$ & $\begin{array}{l}15 \\
11\end{array}$ & $\begin{array}{r}6 \\
22 \\
\end{array}$ & $\begin{array}{l}24 \\
25\end{array}$ & $\begin{array}{l}44^{* \star *} \\
31\end{array}$ & $\begin{array}{l}110 \\
127^{\star}\end{array}$ \\
\hline $\begin{array}{l}\text { Respons } \\
\text { I } \\
\text { II }\end{array}$ & $\begin{array}{l}\text { s } \\
45 \\
18 \\
\end{array}$ & $\begin{array}{l}58 \\
10 \\
\end{array}$ & $\begin{array}{r}57 \\
8\end{array}$ & $\begin{array}{l}93^{\star *} \\
12\end{array}$ & $\begin{array}{l}54 \\
17 \\
\end{array}$ & $\begin{array}{r}52 \\
7\end{array}$ & $\begin{array}{c}359^{\star \star} \\
72\end{array}$ \\
\hline $\begin{array}{l}\text { Perform } \\
\text { I } \\
\text { II }\end{array}$ & $\begin{array}{c}\text { tives } \\
0 \\
1\end{array}$ & $\begin{array}{c}0 \\
10^{* *}\end{array}$ & $\begin{array}{l}0 \\
0\end{array}$ & $\begin{array}{l}3 \\
3\end{array}$ & $\begin{array}{l}5^{*} \\
1 \\
\end{array}$ & $\begin{array}{l}2 \\
3\end{array}$ & $\begin{array}{l}10 \\
18\end{array}$ \\
\hline $\begin{array}{l}\text { Organiz } \\
\text { I } \\
\text { II }\end{array}$ & $\begin{array}{c}\text { tional D } \\
2 \\
14 \\
\end{array}$ & $\begin{array}{c}\text { Devices } \\
2 \\
24 \\
\end{array}$ & $\begin{array}{l}3 \\
3^{*} \\
\end{array}$ & $\begin{array}{r}6 \\
17 \\
\end{array}$ & $\begin{array}{r}3 \\
14 \\
\end{array}$ & $\begin{array}{l}13^{\star} \\
24 \\
\end{array}$ & $\begin{array}{l}29 \\
96^{*} \\
\end{array}$ \\
\hline $\begin{array}{l}\text { Expressi } \\
\text { I } \\
\text { II }\end{array}$ & $\begin{array}{r}3 \\
3 \\
2\end{array}$ & $\begin{array}{l}7 \\
4\end{array}$ & $\begin{array}{l}7 \\
1\end{array}$ & $\begin{array}{l}8 \\
1\end{array}$ & $\begin{array}{r}10 \\
1\end{array}$ & $\begin{array}{l}1 \\
3\end{array}$ & $\begin{array}{l}36 \\
12\end{array}$ \\
\hline $\begin{array}{l}\text { Others } \\
\text { I } \\
\text { II }\end{array}$ & $\begin{array}{l}46 \\
89^{* *}\end{array}$ & $\begin{array}{l}19 \\
16\end{array}$ & $\begin{array}{r}25 \\
7\end{array}$ & $\begin{array}{l}26 \\
16\end{array}$ & $\begin{array}{l}29 \\
23\end{array}$ & $\begin{array}{r}8 \\
13\end{array}$ & $\begin{array}{l}153 \\
164^{\star *}\end{array}$ \\
\hline $\begin{array}{l}\text { Sub-tota } \\
\text { I } \\
\text { II }\end{array}$ & $\begin{array}{l}103 \\
139\end{array}$ & $\begin{array}{r}104 \\
94\end{array}$ & $\begin{array}{c}118 \\
41 \text { ** }\end{array}$ & $\begin{array}{r}143 \\
75 \\
\end{array}$ & $\begin{array}{r}128 \\
84 \\
\end{array}$ & $\begin{array}{r}125 \\
95 \\
\end{array}$ & $\begin{array}{l}721 \\
528 \\
\end{array}$ \\
\hline Total & 242 & 198 & 159 & 218 & 212 & 220 & 1249 \\
\hline
\end{tabular}


Table 1 exhibits the wide range of behaviours used by each subject in both interactions. It is clear, however, that in Interaction $I$, responses were used significantly more than any other category by all the subjects as a group $(p<0.01)$, and that performatives were barely used. In fact three subjects never used any at all. In Interaction II it is comments, and 'Others' that were used significantly more than all the other categories $(p<0.01)$ except organizational devices by all the Ss as a group, and expressives as well as performatives that were hardly used at all by most of the Ss.

These results are not unexpected when considering the level of language development of the Ss and the nature of the interactions. Rees (1978) and Creaghead (1982) document a pragmatic trend in language-impaired children of having a limited range of communication intents in comparison to normally developing children and the tendency for limited use of a variety of speech acts in that kind of partnership.

Table 2: Variation within Linguistic Responses for all subjects in Interaction I and II

\begin{tabular}{|lccccccc|}
\hline Subjects & A & B & C & D & E & F & Total \\
\hline \multicolumn{2}{l}{ Acknowledgements } & & & & & \\
I & 17 & 0 & 3 & 2 & 0 & 0 & 22 \\
II & 0 & 0 & 0 & 4 & 1 & 1 & 6 \\
\hline \multicolumn{2}{l}{ Response to question } & & & & & \\
I & 0 & $4^{*}$ & $4^{*}$ & $85^{* *}$ & $42^{*}$ & $43^{*}$ & $251^{* \star}$ \\
II & 0 & 0 & 1 & 6 & 3 & 0 & 10 \\
\hline Clarification & & & & & & & \\
I & 9 & 16 & 9 & 3 & 0 & 8 & 45 \\
II & 16 & 10 & 3 & 2 & 12 & 6 & 49 \\
\hline Fotals & & & & & & & \\
I & 26 & 57 & 52 & 90 & 42 & 51 & 318 \\
II & 16 & 10 & 4 & 12 & 16 & 7 & 65 \\
\hline
\end{tabular}

** $p<0.01 \quad$ *p $<0,05$

If one looks at the subcategories of by far the largest category of communicative acts (Responses in Interaction I) and separates these into linguistic and non-linguistic responses, it becomes clearer why this form of interaction was so frequently used. Table 2 shows that for every child except Subject A, linguistic responses to questions were significantly the most predominant form of response, al though the level of significance varied $(p<0.01$ and $p<0.05)$ (Subject $A$, in fact, used linguistic responses to questions least of all of his response types.) Remembering that their communicative intents are usually limited, these language impaired subjects used this means of keeping the conversational ball in play, taking turns where required by modifying the adult's interrogative into a declarative sentence. Their non-verbal responses were occasionally indicative of a failure to comprehend the question form.

Table 3: Línguistic/non-linguistic Responses for all subjects in Interactions I and II

\begin{tabular}{|c|c|c|c|c|c|c|c|}
\hline Subjects & $\mathrm{A}$ & B & $\mathrm{C}$ & D & $\mathrm{E}$ & $\mathrm{F}$ & Total \\
\hline $\begin{array}{l}\text { Linguisti } \\
\text { I } \\
\text { II }\end{array}$ & $\begin{array}{l}26 \\
16\end{array}$ & $\begin{array}{l}57^{\star} \\
10\end{array}$ & $\begin{array}{c}52^{\star} \\
4\end{array}$ & $\begin{array}{l}90^{* *} \\
12\end{array}$ & $\begin{array}{l}42^{*} \\
16\end{array}$ & $\begin{array}{c}51^{*} \\
7\end{array}$ & $\begin{array}{r}318 \\
65\end{array}$ \\
\hline $\begin{array}{l}\text { Non-ling } \\
\text { I } \\
\text { II }\end{array}$ & $\begin{array}{l}\text { istic } \\
19^{* *} \\
2 \\
\end{array}$ & $\begin{array}{l}1 \\
0 \\
\end{array}$ & $\begin{array}{l}5 \\
4 \\
\end{array}$ & $\begin{array}{l}3 \\
0\end{array}$ & $\begin{array}{r}12 \\
1\end{array}$ & $\begin{array}{l}1 \\
0\end{array}$ & $\begin{array}{r}41 \\
7\end{array}$ \\
\hline $\begin{array}{l}\text { Totals } \\
\text { I } \\
\text { II }\end{array}$ & $\begin{array}{l}45 \\
18\end{array}$ & $\begin{array}{l}58 \\
10\end{array}$ & $\begin{array}{r}57 \\
8\end{array}$ & $\begin{array}{l}93 \\
12\end{array}$ & $\begin{array}{l}54 \\
17\end{array}$ & $\begin{array}{r}52 \\
7\end{array}$ & $\begin{array}{c}359^{* *} \\
72\end{array}$ \\
\hline
\end{tabular}

** $p<001 \quad$ *p<0.05
There were other means by which the subjects in this study fulfilled their communicative obligations with limited linguistic skills. When the communicative function of non-linguistic behaviours such as symbolic noise or gesture was clear, these were included in the relevant subcategory in Part I of the profile. It turned out that all of these except two (both descriptions), were responses to questions. Table 3 indicates the ratio of linguistic to non-linguistic communicative acts used by each subject as responses in both interactions. Significantly more linguistic behaviours were used by all the children except Subject $A$ in Interaction $I(p<0.05$ or 0.01$)$ where Subject $A$ used significantly more non-linguistic responses $(p<0.01)$.

These findings correlate with a specific pragmatic disability as described by Prutting \& Kirchner (1983) and by Shavakis \& Greenfield (1982) who state that even when the child acknowledges the partnership of a communicative action and is relatively sensitive to his obligation as a participant, what continues to interfere with his communication are higher level linguistic operations.

Table 4: Variation within the "Other" category for all subjects in Interactions I and II.

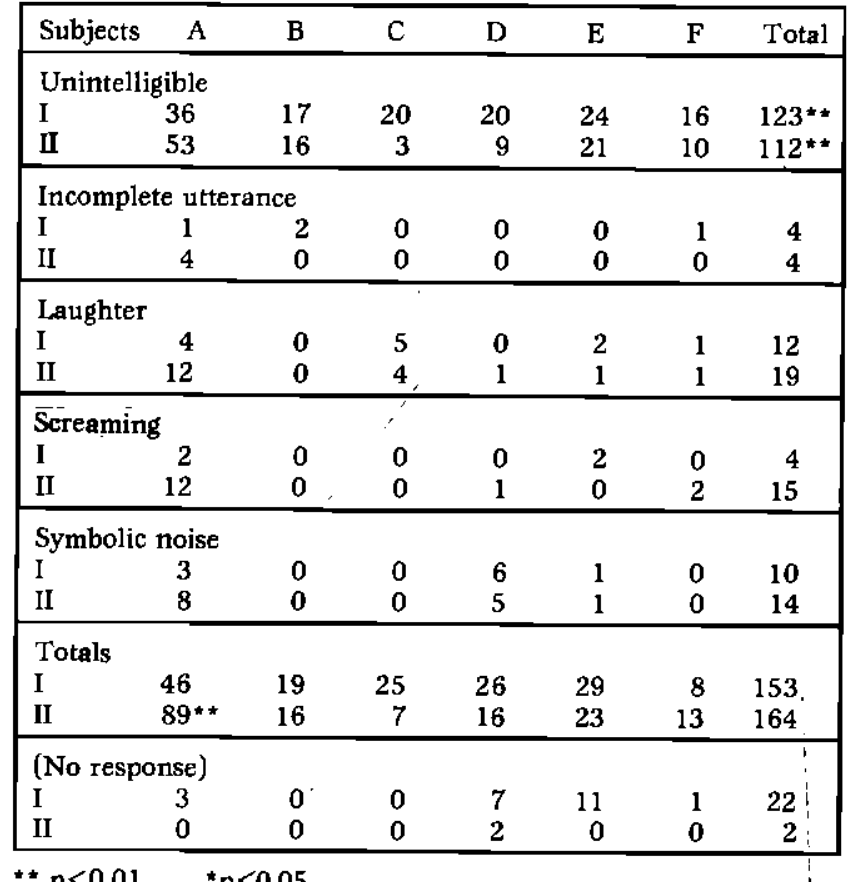

There were more non-linguistic strategies used by the children that become evident when the content of the category' of 'Others' is looked at in table 4 which is seen to contain several non-linguistic communicative acts in addition to the nonlinguistic entries in the other categories. The 'Other' category on Wollner \& Geller's (1982) profile was found to be inadequate for this study in providing space for unintelligible and uninterpretable utterances only. It was therefore modified by combining unintelligible and uninterpretable and adding linguistic and non-linguistic subcategories that were found to be used by the subjects in ways that could not easily be.itemized elsewhere on the profile. The additions are shown in table 4.

The fact that in Interaction II the category of 'Other' was used considerably more than any other category and highly significantly more $(p<0.01)$ than four of the other categories (see table 1) is now explained. Within this category are a large number of unintelligible utterances that could not be catego- 
rized as any other communicative act nor did they specifically introduce or extend the topic of conversation. They served instead to perpetuate the interaction. Subject A produced the largest number of unintelligible utterances, and it is interesting that he used more of these in Interaction II, while all the others used more in Interaction I where they were responding to an adult.

It was also Subject $\mathrm{A}$, who was the least advanced linguistically on the LARSP Profile (Crystal, Fletcher \& Garman (1976), who used symbolic noise, laughter and screaming more than the other children, and this behaviour could be included in those back-channel behaviours that Fey \& Leonard (1983) describe as serving to maintain social contact, and at the same time avoiding taking the conversational floor. If one adds exclamations to these behaviours (the only entry within the Expressive Category for all the Subjects) it is apparent that all the children used this black-channelling as a means for fulfilling their social responsibility.

Referring again to table 1 , Subject $C$ used highly significantly more requests than his peers in Interaction I $(<0.01)$ and significantly more than any of the others $(p<0.05)$ except Subject $F$ who used the most in Interaction II. Subject $C$, however, also used significantly fewer organizational devices $(\mathrm{p}<0.05)$ than the rest in Interaction II and in fact his total number of 159 communicative acts is considerably smaller than all the other children whose totals ranged from 198 to 242 acts.

Table 5: Variation within Organizational Devices for all subjects in Interactions I and II

\begin{tabular}{|c|c|c|c|c|c|c|c|}
\hline Subjects & A & B & C & $\mathrm{D}$ & $\mathrm{E}$ & $\mathrm{F}$ & Total \\
\hline $\begin{array}{l}\text { Attention } \\
\text { I } \\
\text { II }\end{array}$ & $\begin{array}{r}0 \\
0 \\
10 \\
\end{array}$ & $\begin{array}{r}0 \\
22 \\
\end{array}$ & $\begin{array}{l}1 \\
2 \\
\end{array}$ & $\begin{array}{l}1 \\
3 \\
\end{array}$ & $\begin{array}{r}1 \\
10 \\
\end{array}$ & $\begin{array}{l}11 \\
19\end{array}$ & $\begin{array}{l}14 \\
66^{\star}\end{array}$ \\
\hline $\begin{array}{l}\text { Speaker s } \\
\text { I } \\
\text { II } \\
\end{array}$ & $\begin{array}{r}\text { lect } \\
0 \\
0 \\
\end{array}$ & $\begin{array}{l}0 \\
0 \\
\end{array}$ & $\begin{array}{l}0 \\
0 \\
\end{array}$ & $\begin{array}{l}0 \\
2 \\
\end{array}$ & $\begin{array}{l}0 \\
0 \\
\end{array}$ & $\begin{array}{l}0 \\
0 \\
\end{array}$ & $\begin{array}{l}0 \\
2 \\
\end{array}$ \\
\hline $\begin{array}{l}\text { Boundary } \\
\text { I } \\
\text { II }\end{array}$ & $\begin{array}{r}\operatorname{mar} \\
2 \\
4 \\
\end{array}$ & $\begin{array}{l}2 \\
2 \\
\end{array}$ & $\begin{array}{l}2 \\
1 \\
\end{array}$ & $\begin{array}{r}5 \\
12 \\
\end{array}$ & $\begin{array}{l}2 \\
3 \\
\end{array}$ & $\begin{array}{l}2 \\
5 \\
\end{array}$ & $\begin{array}{l}15 \\
27 \\
\end{array}$ \\
\hline $\begin{array}{l}\text { Politeness } \\
\text { I } \\
\text { II }\end{array}$ & $\begin{array}{r}\operatorname{mar} \\
0 \\
0\end{array}$ & $\begin{array}{l}0 \\
0\end{array}$ & $\begin{array}{l}0 \\
1 \\
0 \\
\end{array}$ & $\begin{array}{l}0 \\
0\end{array}$ & $\begin{array}{l}0 \\
1 \\
\end{array}$ & $\begin{array}{l}0 \\
0 \\
\end{array}$ & $\begin{array}{l}0 \\
1\end{array}$ \\
\hline $\begin{array}{l}\text { Totals } \\
\text { I } \\
\text { II }\end{array}$ & $\begin{array}{r}2 \\
14\end{array}$ & $\begin{array}{r}2 \\
24\end{array}$ & $\begin{array}{l}3 \\
3 \\
3 \\
\end{array}$ & $\begin{array}{r}6 \\
17\end{array}$ & $\begin{array}{r}3 \\
14\end{array}$ & $\begin{array}{l}13 \\
24\end{array}$ & $\begin{array}{l}29 \\
96\end{array}$ \\
\hline
\end{tabular}

The children in this study used one organizational device much more than any other. The bulk of the entries for Interaction II in the Organizational Device category in table 5 are attention-getters (used significantly more than other organizational devices by all the children as a group in Interaction II), indicating the importance of this behaviour in the subjects' repertoire of communicative skills in certain communicative contexts. In Interaction 1 the attention of the adult was focused exclusively on the child, and all the subjects, were aware of this, while in Interaction II both children's attention was focused primarily on themselves in play, with one or other child being content occasionally to play alone without involvement with the other member of the dyad. Attentiongetters were therefore necessary to re-initiate the communicative interaction.

McTear (1985) \& Ochs, Schieffelin \& Platt(1979) discuss how lexical attention-getters are used by children as young as two years old. Mueller (1972) showed that the frequency of occurrence of attention-getter increases with age, and found it to be a function of the child's developing communicative competence. In contrast, only one of the six children, Subject $\mathrm{E}$, employed a politeness marker, and this child used it only twice in spite of numerous potential occasions for him and the other subjects. Leonard, Nippold, \& Anastopoulous (1982) elaborate on the emergence of politeness markers and relate them to the ability of the child to adopt the perspective of the other person, but there is no available information on this skill in language impaired children.

If one compares the total number of utterances produced by each subject in each interaction in table 1 , it is only Subject A who apparently talked a lot more in Interaction II. It seems he is therefore the only child who conformed with Fey, Leonard \& Wilcox's (1981) language impaired subjects who spoke more frequently with their peers than with others, but this observation must be viewed in the light of the fact that he produced many more non-linguistic utterances than the other subjects (see table 4).

Table 6: Topic initiation \& extension for all subjects in Interactions I and II

\begin{tabular}{|lrrrrrrr|}
\hline Subjects & A & B & C & D & E & F & Total \\
\hline Initiation & & & & & & & \\
I & 0 & 0 & 2 & -1 & 3 & 12 & 18 \\
II & 12 & 13 & 7 & 9 & 16 & 15 & 71 \\
Total & 12 & 13 & 9 & 10 & 19 & 27 & 90 \\
\hline Extension & & & & & & & \\
I & 37 & 94 & 88 & 96 & 88 & 90 & 493 \\
II & 27 & 64 & 26 & 57 & 46 & 91 & 311 \\
Total & 64 & 158 & 114 & 153 & 134 & 181 & 804 \\
\hline
\end{tabular}

Although all six subjects used more responses as communicative acts than comments with the adult, and reversed this trend in the interaction with their peer (see table 1), it is apparent in table 6 that when the subjects' interactions are looked at as conversational acts, all the children were extenders of topics rather than initiators in both interactions. This appears not to conform with the above findings about comments being dominant in Interaction II, but if one considers that topic extension includes more than responses, it is clear there is no anomaly. The subjects were in fact confirming the findings of several authors including Donahue (1983) who reports that the stronger communicative partner generally assumes responsibility for maintaining the dialogue, and Siegel, Cunningham and van der Spuy cited by Fey \& Leonard (1983), who describe how, in interaction with familiar adults, language impaired children are less likely to iniate interaction.

Table 7 shows the variety of ways in which the subjects extended the topics in both interactions. It is clear that the majority of extensions at a highly significant level $(p<0.01)$ occurred for all the children as a group in both interactions as topic relevant extensions when they were related to the content of the previous speaker's act, but went further by adding to it.

Further, these topic relevant extensions were used considerably more in Interaction I by each subject. Subject D was the only subject who used more acknowledgements than topic relevant extensions in Interaction I, although Subject B's use of each was almost equal. Wollner \& Geller (1982) stress the important notion that the child's ability to sustain the topic 
with relevant contributions over extended turns depends on the conversational partner and the partner's sensitivity to the child's cognitive and linguistic level.

Table 7: Variation within Topic Extension for all subjects in Interactions I and II.

\begin{tabular}{|c|c|c|c|c|c|c|c|}
\hline Subjects & $\mathrm{A}$ & $\mathrm{B}$ & $\mathrm{C}$ & $\mathrm{D}$ & $\mathrm{E}$ & $\mathrm{F}$ & Total \\
\hline \multicolumn{8}{|c|}{ Acknowledgements } \\
\hline & $5 *$ & 33 & 17 & 56 & 28 & 27 & 166 \\
\hline II & 6 & 2 & 0 & 17 & 5 & 9 & 39 \\
\hline \multicolumn{8}{|c|}{ Topic relevant } \\
\hline & 20 & 35 & 45 & 32 & 45 & 63 & $240^{* *}$ \\
\hline II & 7 & 19 & 11 & 30 & 21 & 52 & $140^{\star *}$ \\
\hline \multicolumn{8}{|l|}{ Topic shift } \\
\hline & 0 & 1 & 2 & 0 & 1 & 0 & 4 \\
\hline & 1 & $24^{* *}$ & 4 & 2 & 0 & 4 & 35 \\
\hline \multicolumn{8}{|l|}{ Off topic } \\
\hline & 1 & 3 & 4 & 2 & 4 & 0 & 14 \\
\hline & & & $\underline{0}$ & 0 & 0 & 3 & 14 \\
\hline \multicolumn{8}{|c|}{ Resume topic } \\
\hline & 1 & 1 & 0 & 0 & 0 & 0 & 2 \\
\hline II & 1 & 5 & 0 & 2 & 7 & 15 & 30 \\
\hline \multicolumn{8}{|c|}{ Clarification request } \\
\hline & 0 & 1 & 6 & 1 & 0 & 0 & 8 \\
\hline II & 0 & 2 & 6 & 2 & 2 & 2 & 14 \\
\hline \multicolumn{8}{|c|}{ Clarification response } \\
\hline I & 9 & 17 & 11 & 3 & 7 & 0 & 47 \\
\hline II & 7 & 3 & 4 & 2 & 10 & 6 & 32 \\
\hline \multicolumn{8}{|l|}{ Totals } \\
\hline & 36 & 91 & 85 & 94 & 85 & 90 & 481 \\
\hline II & 25 & 63 & 25 & 55 & 45 & 91 & 304 \\
\hline
\end{tabular}

All the children except Subject $C$ used more comments than verbal responses in Interaction II (see table 1) and all the subjects initiated more topics in Interaction II than in Interaction I (see table 6). These findings support those on Fey, Leonard \& Wilcox (1981) who found that the language impaired subjects they studied became more assertive when interacting with other language impaired children. One child, Subject F, used almost the same number of comments and responses with the adult, and many more comments than the other children in both interactions (see table 1). He was also the only child who initiated as many topics as those he extended (see table 6). It is important to note that this child was the oldest and most advanced linguistically on his LARSP profile (Crystal, Fletcher \& Garman (1976)).

When the subjects were asked for clarificarion of their utteran. ces, it was more frequently by the adult in Interaction I, but in Interaction II, all the children except Subject A signalled a need for repair (see table 7). Table 8 shows that Subject A was also the only child who responded to a request for clarification with a nonverbal response in either interaction, and his only other attempt to repair was by repetition of his unintelligible utterances without attempting to modify them but all of them utteranced without attempting to modify them but all of them except Subject $D$ also attempted some other means of clarification, with Subject B producing a wide repertoire. The children were generally very tolerant of clarification requests, and occasionally responded with up to four successive clarification attempts. They also requested acknowledgement after their clarification responses to ensure that their message had been understood.

Gallagher (1977) also found that regardless of language age, no subject ignored requests for clarification, although the responses were dependent on the level of his structural knowledge. Donahue, Pearl \& Bryan (1980) on the other hand, report the trend that language impaired children are less likely to initiate repair of communication breakdown and hence appear to be less co-operative communication partners. This is confirmed in the present study if the latter authors' finding refers to requests for clarification (see table 7).

Table 8: Responses to Clarification Requests for all subjects in Interactions $I$ and $I I$.

\begin{tabular}{|c|c|c|c|c|c|c|c|}
\hline Subjects & A & B & $\mathrm{C}$ & D & $\mathbf{E}$ & $\mathrm{F}$ & Total \\
\hline $\begin{array}{l}\text { No repair } \\
\text { I } \\
\text { II }\end{array}$ & $\begin{array}{l}2 \\
4 \\
\end{array}$ & $\begin{array}{l}4 \\
1 \\
\end{array}$ & $\begin{array}{l}0 \\
0 \\
\end{array}$ & $\begin{array}{l}1 \\
0 \\
\end{array}$ & $\begin{array}{l}0 \\
0\end{array}$ & $\begin{array}{l}0 \\
1 \\
\end{array}$ & $\begin{array}{l}7 \\
6 \\
\end{array}$ \\
\hline $\begin{array}{l}\text { Repetition } \\
\text { I } \\
\text { II } \\
\end{array}$ & $\begin{array}{l}2 \\
3 \\
\end{array}$ & $\begin{array}{l}4 \\
1 \\
\end{array}$ & $\begin{array}{l}5 \\
3 \\
\end{array}$ & $\begin{array}{l}2 \\
2 \\
\end{array}$ & $\begin{array}{l}3 \\
4 \\
\end{array}$ & $\begin{array}{l}0 \\
4 \\
\end{array}$ & $\begin{array}{l}16 \\
17 \\
\end{array}$ \\
\hline $\begin{array}{l}\text { Syntac/sem } \\
\text { I } \\
\text { II }\end{array}$ & $\begin{array}{l}\text { Ianti } \\
0 \\
0 \\
\end{array}$ & $\begin{array}{c}\text { visio } \\
1 \\
0 \\
\end{array}$ & $\begin{array}{l}3 \\
0 \\
\end{array}$ & $\begin{array}{l}0 \\
0 \\
\end{array}$ & $\begin{array}{l}2 \\
5 \\
\end{array}$ & $\begin{array}{l}0 \\
0 \\
\end{array}$ & $\begin{array}{l}6 \\
5 \\
\end{array}$ \\
\hline $\begin{array}{l}\text { Paraphrase } \\
\text { I } \\
\text { II } \\
\end{array}$ & $\begin{array}{l}0 \\
0 \\
\end{array}$ & $\begin{array}{l}0 \\
0 \\
\end{array}$ & $\begin{array}{l}1 \\
0 \\
\end{array}$ & $\begin{array}{l}0 \\
0 \\
\end{array}$ & $\begin{array}{l}0 \\
0 \\
\end{array}$ & $\begin{array}{l}0 \\
0 \\
\end{array}$ & $\begin{array}{l}1 \\
0 \\
\end{array}$ \\
\hline $\begin{array}{l}\text { Part repetiti } \\
\text { I } \\
\text { II }\end{array}$ & $\begin{array}{l}\text { ion } \\
0 \\
0 \\
\end{array}$ & $\begin{array}{l}2 \\
1 \\
\end{array}$ & $\begin{array}{l}0 \\
0 \\
\end{array}$ & $\begin{array}{l}0 \\
0 \\
\end{array}$ & $\begin{array}{l}1 \\
0 \\
\end{array}$ & $\begin{array}{l}0 \\
0\end{array}$ & $\begin{array}{l}2 \\
1 \\
\end{array}$ \\
\hline $\begin{array}{l}\text { Unintelligib } \\
\text { I } \\
\text { II } \\
\end{array}$ & $\begin{array}{l}1 \text { e } \\
0 \\
0 \\
\end{array}$ & $\begin{array}{l}1 \\
0 \\
\end{array}$ & $\begin{array}{l}0 \\
0 \\
\end{array}$ & $\begin{array}{l}0 \\
0 \\
\end{array}$ & $\begin{array}{l}1 \\
0 \\
\end{array}$ & $\begin{array}{l}0 \\
0 \\
\end{array}$ & $\begin{array}{l}2 \\
0 \\
\end{array}$ \\
\hline $\begin{array}{l}\text { Multiple rep } \\
\text { I } \\
\text { II } \\
\end{array}$ & $\begin{array}{l}\text { peti } \\
0 \\
0 \\
\end{array}$ & $\begin{array}{l}2 \\
0 \\
\end{array}$ & $\begin{array}{l}0 \\
0 \\
\end{array}$ & $\begin{array}{l}0 \\
0 \\
\end{array}$ & $\begin{array}{l}0 \\
1 \\
\end{array}$ & $\begin{array}{l}0 \\
0 \\
\end{array}$ & $\begin{array}{l}2 \\
1 \\
\end{array}$ \\
\hline $\begin{array}{l}\text { Incomplete } \\
\text { I } \\
\text { II } \\
\end{array}$ & $\begin{array}{l}\text { clar } \\
0 \\
0 \\
\end{array}$ & $\begin{array}{c}\text { tion } \\
1 \\
0 \\
\end{array}$ & $\begin{array}{l}0 \\
0 \\
\end{array}$ & $\begin{array}{l}0 \\
0 \\
\end{array}$ & $\begin{array}{l}0 \\
0 \\
\end{array}$ & $\begin{array}{l}0 \\
0 \\
\end{array}$ & $\begin{array}{l}1 \\
0 \\
\end{array}$ \\
\hline $\begin{array}{l}\text { Request ack } \\
\text { I } \\
\text { II } \\
\end{array}$ & $\begin{array}{l}\text { nor } \\
0 \\
0 \\
\end{array}$ & $\begin{array}{c}\text { gem } \\
2 \\
0 \\
\end{array}$ & $\begin{array}{l}2 \\
1 \\
\end{array}$ & $\begin{array}{l}0 \\
0 \\
\end{array}$ & $\begin{array}{l}0 \\
0 \\
\end{array}$ & $\begin{array}{l}0 \\
1 \\
\end{array}$ & $\begin{array}{l}4 \\
2 \\
\end{array}$ \\
\hline $\begin{array}{l}\text { Non-verbal } \\
\text { I } \\
\text { II } \\
\end{array}$ & $\begin{array}{l}\text { cla } \\
5 \\
0\end{array}$ & $\begin{array}{c}\text { tior } \\
0 \\
0 \\
\end{array}$ & $\begin{array}{l}0 \\
0\end{array}$ & $\begin{array}{l}0 \\
0 \\
\end{array}$ & $\begin{array}{l}0 \\
0 \\
\end{array}$ & $\begin{array}{l}0 \\
0 \\
\end{array}$ & $\begin{array}{l}5 \\
0 \\
\end{array}$ \\
\hline $\begin{array}{l}\text { Totals } \\
\text { I } \\
\text { II }\end{array}$ & $\begin{array}{l}9 \\
7 \\
\end{array}$ & $\begin{array}{r}17 \\
3 \\
\end{array}$ & $\begin{array}{r}11 \\
4 \\
\end{array}$ & $\begin{array}{l}3 \\
2 \\
\end{array}$ & $\begin{array}{r}7 \\
10 \\
\end{array}$ & $\begin{array}{l}0 \\
6 \\
\end{array}$ & $\begin{array}{l}47 \\
32 \\
\end{array}$ \\
\hline
\end{tabular}

It is worth noting that all six subjects differed significantly from all of their peers in at least one type of communicative act. This serves to remind us of the heterogeneity of the communicative behaviour of language impaired children, but may also be due to the sampling procedure of this study. Roth \& Spekman (1984a) discuss various limitations of assessment in naturalistic settings. They comment on how analysis of the data is always limited to what a child produces, that the mere absence of a particular communicative intent or failure to initiate new topics cannot necessarily be seen as an indication that such a skill is not part of the child's repertoire, and that the presence of a particular communicative behaviour may not be demonstrated with sufficient frequency to assess its adequacy. These limitations apply to assessment within a váriety of naturalistic settings, and the results from the present investigation should be considered in this framework. The relevance of these comments can be highlighted, for example, by the results obtained regarding politeness markers which may well have been used more by these children in settings with less familiar communicative partners. 
A further comment has been made by Fey, Leonard \& Wilcox (1981) who state that in conversation, each participant brings a combination of perceptual, social, cognitive and linguistic skills to the task. They warn against viewing any of these variables in isolation. Galllagher (1983) confirms this opinion and introduces issues of personality that need to be considered in discussing a child's communicative competence. She also cites extensive evidence that suggests that there is a significant interrelationship between language use variability and every aspect of physical context that probably can, but will not necessarily, effect a particular child's language use (Gallagher 1983). She concedes, however, that sampling across a limited number of contextual environments meets the practical requirement of efficiency (Gallagher 1983).

\section{CONCLUSION}

Results of the present investigation serve to emphasise the heterogeneity that exists in children with language disorders and in pragmatic trends as they relate to syntactic development. The study also highlights the variety of pragmatic abilities displayed by the language disordered children studied and exemplifies both patterns of strength and weaknesses as exhibited by them and as reported in the literature. It has been established here that these children use a variety of communicative acts and non-linguistic communication to compensate for limited linguistic skills and that they understand that communication is a symbol sharing system that requires co-operative partners. Identification of each child's patterns of interaction within the boundaries of the sampling procedures used in the study adds to the assessment data for the incorporation into the therapy goals for increasing the overall effectiveness of the child's communication.

\section{ACKNOWLEDGEMENTS}

Sincere thanks are extended to the speech and hearing therapist at the Language Unit at Groote Schuur Hospital for her co-operative participation in the study, to the children at the Language Unit who were the subjects in the investigation, and to the Teaching Methods Unit at the University of Cape Town for their videotape recording service.

\section{REFERENCES}

Bates, B. Language and Context: The acquisition of pragmatics. New York: Academic Press Incorporated, 1976.

Brinton, B. and Fujiki, M. A comparison of request response sequences in the discourse of normal and language disordered children. Journal of Speech and Hearing Disorders, 47(1), 57-62, 1982 .

Corsaro, W.A. The development of social cognition in preschool children: Implications for language learning. Topics in Language Disorders 1(2), 77-95 1979.

Craig, H.K. Applications of pragmatic language models for intervention. In T.M. Gallagher and C A Prutting (eds), Pragmatic Assessment and Intervention Issues in Language. California: College Hill Press, 1983.

Creaghead, N. Children with disorders of pragmatics In JV Irwin (Ed), Pragmatics: The Role in Language Development. California: Fox Point Publishing Ltd, 1982.

Crystal, D., Fletcher, P., and Garman, M. The Grammatical Analysis of Language Disability: A Procedure for Assessment and Remediation. London: Edward Arnold, 1976.

Donahue, M. Learning disabled children as conversational partners. Topics in Language Disorders, 15, 25-37, 1983.

Donahue, J., Gearhart, M., \& Newman, D. Conversation competence in lea rning disabled children: responses to uninformative messages. Applied Psycholinguistics, 1, 387-403, 1980.

Dore, J., Gearhart, M., and Newman, D. The structure of nursery school conversation. In K Nelson (Ed), Children's Language, vol 1. New York: Gardner Press, 371-372, 1978.
Fey, M., and Leonard L. Pragmatic skills of children with specific language impairment. In T.M. Gallagher and C A Prutting (Eds), Pragmatic Assessment and Intervention in Language. California: College Hill Press, 1983.

Fey, M., Leonard, L., and Wilcox, K. Speech style modifications of language impaired children. Journal of Speech and Hearing Disorders, 46, 91-96, 1981.

Gallagher, T.M. Revision behaviours in the speech of normal children developing language. Journal of Speech and Hearing Research, $20,305-318,1977$.

Gallagher, T.M. Pre-assessment: a procedure for accommodating language use variability. In T.M. Gallagher and C A Prutting (Eds), Pragmatic Assessment and Intervention Issues in Language. California: College Hill Press, 1983.

Gallagher, T.M. Darnton B A. Conversational aspects of the speech of language disordered children: revision behaviours. Journal of Speech and Hearing Research, 21, 118-135, 1978.

Grice, H.P. Logic and conversation. In P. Cole and J. Morgan (Eds), Studies in Syntax and Semantics, Speech Acts (3). New York: Academic Press 1975.

Leonard, L., Nippold, M., and Anastopoulous, A. Development in the use of and understanding of polite forms in children. Journal of Speech and Hearing Research, 25, 193-202, 1982.

McTear, M.F. Children's Conversations. Oxford: Blackwell Publishers, Oxford, 1985.

Mueller, E. The maintenance of verbal exchanges between young children. Child Development, 43(3), 930-938, 1972.

Muma, J.R. The communication game: dump and play. Journal of Speech and Hearing Disorders, 40, 296-307, 1975.

Ochs, E., and Schieffelin, B. (eds). Developmental Pragmatics. New York: Academic Press 1979.

Ochs, E. Transcription as theory. In E Ochs and B. Schieffelin (Eds), Developmental Pragmatics. New York; Academic Press, 43-72 1979 .

Ochs, E., Schieffelin, B., and Platt, M. Propositions across utterances and speakers. In E. Ochs and B. Schieffelin (Eds), Developmental Pragmatics. New York: Academic Press, 251-268, 1979.

Penn, C. The profile of communicative appropriateness. A clinical tool for the assessment of pragmatics. South African Journal of Communication Disorders, 32, 18-25, 1985.

Prinz, P. Development of pragmatics: multiword level. In J V Irwin (Ed), Pragmatics - The Role in Language Development. California: Fox Point Publishing Ltd, 1982.

Prutting, C., and Kirchner, D. Applied pragmatics In T M Gallagher and C A Prutting (Eds) Pragmatic Assessment and Intervention Issues in Language. California: College Hill Press, 1983.

Rees, N. Pragmatics of language: applications to normal and disordered language development. In R. Schiefelbusch (Ed), Bases of Language Intervention. Baltimore: University Park Press 1978.

Roth, F.P., and Spekman, N.J. Assessing the pragmatic abilities of children: part 1: Organizational framework and assessment parameters. Journal of Speech and Hearing Disorders, 42, 2$11,1984(a)$.

Roth, F.P., and Spekman, N.J. Assessing the pragmatic abilities of children: part 2. Guidelines, considerations and specific evaluation procedures. Journal of Speech and Hearing Disorders, 49, $12-17,1984(\mathrm{~b})$.

Savich, P. Improving communication competence - the role of metapragmatic awareness. Topics in Language Disorders, 15 ?.8$47,1983$.

Shavakis, E., and Greenfield, P. The role of new-old information in the verbal expression of language-disordered children. Journal of Speech and Hearing Research, 25, 462-467, 1982.

Shatz, M., and Gelman, R. The development of communication skills: modifications in the speech of young children as a function of the listener. Monographs of the Society for Research in Child Development. 38-47, 1973.

Van Kleeck and Frankel, T.L. Discourse devices used by langugge disordered: a preliminary investigation. Journal of Speech and Hearing Disorders, 46(3), 250-257, 1981.

Wiig, E.G. and Semel, E. Language Assessment and Intervention for the Learning. Disabled. 2nd Edition. Ohio: Charles Merrill Publishing Company, 1986.

Wollner, S. and Geller, E. Methods of assessing pragmatic abilities, In J.V. Irwin (Ed), Pragmatics - The Role in Language Development. California: Fox Point Publishing Limited, 1982. 
APPENDIX 1

Communication Profile

Part 1

\begin{tabular}{|c|c|c|c|c|c|}
\hline \multicolumn{2}{|c|}{$\begin{array}{l}\text { Child's Name } \\
\text { Context: } \\
\text { Dates: }\end{array}$} & \multicolumn{4}{|c|}{$\begin{array}{l}\text { Sima Gerber Wollner } \\
\text { Elaine Geller }\end{array}$} \\
\hline I. COMMUNICATIVE ACTS* & \multicolumn{2}{|c|}{ Speaker } & \multicolumn{3}{|c|}{ Listener } \\
\hline 1. CONVEY CONTENT & Ling & Non-ling** & Ling & \multicolumn{2}{|c|}{ Non-ling } \\
\hline Requests & . & & & & \\
\hline $\begin{array}{l}\text { 1. Action or Object } \\
\text { 2. Information } \\
\text { 3. Permission } \\
\text { 4. Clarification }\end{array}$ & & & & & \\
\hline B. Comments & & & & & \\
\hline $\begin{array}{l}\text { 1. Labels } \\
\text { 2. Descriptions } \\
\text { 3. Attributions } \\
\text { 4. Rules } \\
\text { 5. Explanations }\end{array}$ & & & & & \\
\hline C. Responses & & & & & \\
\hline $\begin{array}{l}\text { 1. Acknowledgements } \\
\text { 2. To Questions } \\
\text { 3. Clarifications }\end{array}$ & & & & & \\
\hline D. Performatives & & & & & \\
\hline $\begin{array}{l}\text { 1. Claims } \\
\text { 2. Jokes } \\
\text { 3. Protests }\end{array}$ & & & & & \\
\hline 2. REGULATE CONVERSATION & & & & & \\
\hline $\begin{array}{l}\text { Organizational Devices } \\
\text { 1. Attention Getters } \\
\text { 2. Speakers Selections } \\
\text { 3. Boundary Markers } \\
\text { 4. Politeness Markers }\end{array}$ & & & & & \\
\hline 3. EXPRESS ATTITUDES & & & & & \\
\hline Expressives & & & & & \\
\hline $\begin{array}{l}\text { 1. Express Emotions } \\
\text { 2. Exclamations }\end{array}$ & & & & & \\
\hline 4. OTHER & & & & & \\
\hline A. Uninterpretable & & & & & \\
\hline B. Unintelligible & & & & & \\
\hline TOTAL COMMUNICATIVE ACTS & & & & & \\
\hline UMMARY - SPEAKER & & & & Yes & No \\
\hline The child expresses a range of & nuni & types. & & & \\
\hline The child uses non-linquistic d & to & ate acts. & & & \\
\hline The child conveys communicati & is cle & & & & \\
\hline The child uses a variety of form & $\exp$ & municativ & & & \\
\hline The child uses appropriste form & expr & unicativ & & & \\
\hline The child uses directindirect f & & काषиा & & & \\
\hline
\end{tabular}

* (Adapted from the work of Dore, Gearhart \& Newman, 1978.)

** (Non-linguistic includes gaze, gesture, intonation, facial expression and vocalization.)

\section{Communication Profile}

Part II

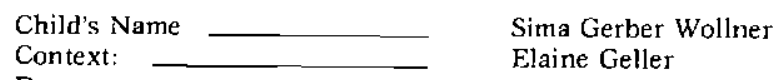

Dates:

\begin{tabular}{l|l|l|l|l}
\hline \multirow{2}{*}{ II. CONVERSATIONAL ACTS* } & \multicolumn{2}{|c|}{ Speaker } & \multicolumn{2}{c}{ Listener } \\
\cline { 2 - 5 } & Ling & Non-ling & Ling & Non-ling \\
\hline 1. INITIATE INTERACTION/ & & & & \\
TOPIC & & & & \\
\hline A. Establish joint attention/ & & & & \\
activityireference. & & & & \\
\hline 2. EXTEND INTERACTION/ & & & & \\
TOPIC & & & & \\
\hline A. Acknowledgement & & & & \\
B. Topic relevant & & & & \\
C. Topic shift & & & & \\
D. Off topic & & & & \\
E. Resume topic & & & & \\
F. Clarification request & & & & \\
G. Clarification response & & & & \\
\hline
\end{tabular}

3. TERMINATE INTERACTION

TOPIC

\begin{tabular}{l|l|l}
\hline SUMMARY - SPEAKER & Yes & No \\
\hline 1. The child initiates topics/interaction. & & \\
\hline 2. The child initiates topics in an appropriate way & & \\
\hline 3. The child extends topics/interaction. & & \\
\hline $\begin{array}{l}\text { 4. The child extends topics with appropriate/relevant } \\
\text { conversational contributions. }\end{array}$ & & \\
\hline $\begin{array}{l}\text { 5. The child uses a variety of conversational acts to } \\
\text { extend topic. }\end{array}$ & & \\
\hline 6. The child extends topies/interaction over successive turns & & \\
\hline
\end{tabular}

*(Adapted from the work of Corsaro, 1979) 


\section{Definitions of Communicative Acts}

\section{Convey Content}

A. Requests involve soliciting information or actions.

1. Requests for action/object involve the speaker directing the listener to perform an action, e.g., gimme ride.

2. Requests for information involve the speaker obtaining solicited information from another participant, e.g., what did you watch on TV?

3. Requests for permission involve the speaker seeking permission to perform an action, e.g., can I go out?

4. Requests for clarification involve the speaker seeking clarification of another person's remark, e.g., what did you say?

B. Comments include descriptions and/or identification of observable events in the environment and statements which report facts or state rules.

1. Labels involve identification of objects, events, persons, etc., e.g., that's a car.

2. Description predicate information about events, properties or locations of people or objects, e.g., it fall down.

3. Attributions report a speaker's beliefs about another person's internal state, e.g., it's too hard for him.

4. Rules state procedure, definitions, "social rules" or facts, e.g., we don't fight in school.

5. Explanations involve the speaker stating reasons, causes, or justification for someone's behaviour, e.g. I hit him because I don't like him.

$C$. Responses involve the speaker providing solicited information to another speaker's prior remark or the acknowledgement of another speaker's prior utterance.

1. Acknowledgements involve the speaker recognizing another participant's prior remark using verbal fillers which merely accompany the interaction without providing new/or additional information, e.g., right or yeah.

2. Responses to questions involve the speaker providing the solicited information to a wh-Question or yes/no question.

3. Clarifications involve clarification of the speaker's previous remark usually in direct response to a clarification request.

D. Performatives accomplish acts and establish facts by being said.

1. Claims involve the speaker establishing his rights, e.g., that's mine; I go first.

2. Jokes involve the speaker causing some humorous effect by stating incongruous information which is usually false, e.g., we throwed the soup in the ceiling.

3. Protests involve the 'speaker expressing some objections to another individual's behaviour, e.g., stop that, no.

\section{Regulate Conversation}

A. Organizational devices accompany an interactional exchange and control the conversation flow and maintain personal contact with the other speaker(s).

1. Attention getters involve the speaker attempting to

- gain the listener's attention, e.k. hey, jonn.

2. Speaker selection involve labelling the next speaker's turn, e.g., you go, your turn.

3. Boundary markers are used to mark openings, closings, or shifts in the conversation, e.g., hi-bye, oh, or bye the way.

4. Politeness markers involve the explicit use of polite forms, e.g., thank you, please.

\section{Express Attitudes}

A. Expressives involve the conveying of feelings or attitudes.

1. Express emotions involves the speaker conveying emotions, feelings or attitudes, e.g., I hate you.

2. Exclamations involve the speaker expressing feelings or attitudes through the use of non-propositional language forms, e.g., wow, yuch!

(Adapted from the work of Dore, Gearhart \& Newman, 1978)

\section{APPENDIX 3}

\section{Definitions of Conversational Acts}

\section{Initiate Interaction/Topic}

A. Establish joint attention/activity/reference refers to any act which encourages a focused interaction by at least two participants in terms of a specified activity or a specified content.

1. Non-linguistically - child shows or offers a toy to the adult; e.g., child points to his milk.

2. Linguistically, the child says Hey, look at this. or Wanna play with play-doh?

\section{Extend Interaction/Topic}

A. Acknowledgement is a non-linguistic or linguistic act which is a response to a previous act but doesn't go beyond in terms of content. Here, we can include responses to ves/no questions, as well as responses to nonrequests. For example,

Child A: I like Popeye.

Child B: Right.

B. Topic relevant acts are related to the content of the previous speaker's act and go beyond or add to the previous act in terms of content. These can be thought of as further contributions to the conversation. For example, Mother: Look at Big Bird.

Child: Big bird has feathers.

C. Topic shift is any act which takes place during a focused interaction where there is a direct attempt to change the topic. In our svstem, unlike Corsaro's. these may or may not be marked formally i.e., Let's do this now.

D. Off-topic acts occur within a focused interaction, are not relevant to the topic, and are usually initiated without a formal marker.

E. Resume topic is any act which refers back to a previously introduced topic.

F. Clarification requests are acts which call for the clarification, confirmation, or repetition of a preceding act. These usually take the form of interrogatives. For example, What did you say? or What do you mean?

$\mathrm{G}$. Clarification responses are acts which are direct reactions to clarification requests. The clarification responses do not go beyond the information or behaviour requested.

\section{Terminate interaction/Topics}

This refers to any act which leads to the end of a focused interaction.

A. Non-linguistically, this might involve a physical movement away from the interaction or no response.

B. Linguistically, it might involve verbal cueing to terminate the interaction, e.g.,

Child: bye-bye

Child: no more book

(Adapted from the work of Corsaro, 1979) 


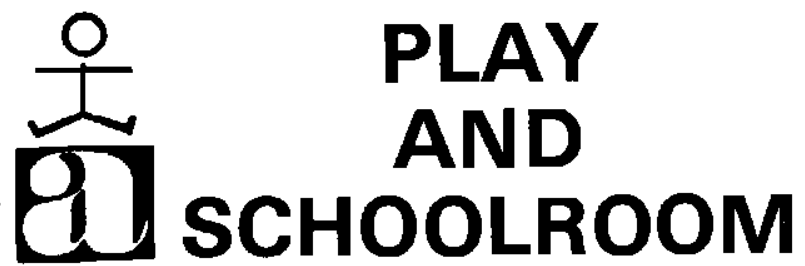

\section{HAVE MOVED TO BIGGER AND BETTER PREMISES}

\author{
AT \\ SHOP 6L THE ROSEBANK MEWS \\ 173 OXFORD ROAD \\ ROSEBANK JHB.
}

PLAY \& SCHOOLROOM, specialists in the field of child education have been offering assistance to both professionals and parents for nearly thirty years.

Their expertise and advice range through pre-school education, perceptual training, primary and remedial education and adult education.

Play and Schoolroom are sole agents for learning development aids which includes an excellent selection of materials of interest to the speech therapist. They also offer an interesting range of aids and books to foster and develop language and communicative skills.

Their stock of educational books and toys is exceptionally wide. You are invited to view their superb range in their new beautifully laid out showroom.

PHONE 788-1304

PO BOX 52137

(as before)

SAXONWOLD

FAX: 880-1341

2132 